\title{
HUBUNGAN MOTIVASI DAN KEMANDIRIAN BELAJAR MAHASISWA CALON GURU SEKOLAH DASAR
}

\author{
Aisa Nikmah Rahmatih ${ }^{1}$, Asri Fauzi ${ }^{2}$, Ida Ermiana ${ }^{3}$ \\ 1,2,3 Program Studi PGSD, FKIP, Universitas Mataram \\ easrifauzi@unram.ac.id ${ }^{1}$
}

\begin{abstract}
This study aims to find out how the relationship between learning motivation and learning independence of prospective elementary school teacher students. Samples used as respondents in this study were 52 PGSD students at Mataram University. Data collection instruments using a questionnaire of motivation and independence of learning questionnaire consisting of 30 items statement. The form of the questionnaire used in this study was a Likert scale questionnaire with 4 alternative choices of answers. The data analysis technique used is the Pearson Product Moment correlation test. Before the correlation test is performed, it must first meet the classical assumption test requirements, namely the normality test and the linearity test. The normality test results obtained sig. (0.927) more than 0.05 then the data is normally distributed, then the linearity test results obtained sig. (0.603) more than 0.05 then there is a linear relationship between the two variables. The results of the Pearson Product Moment correlation test showed the value of sig. ( 2 tailed) 0,000 less than 0.05 and $\mathrm{R}_{\text {value }}(0.849)$ more than $\mathrm{R}_{\text {table }}(0.279)$ which means that there is a significant relationship between motivation and student learning independence, and the resulting degree of relationship is the relationship motivation with student learning independence correlates perfectly.
\end{abstract}

Keywords: learning motivation, learning independence, college student

\begin{abstract}
Abstrak: Penelitian ini bertujuan untuk mengetahui bagaimana hubungan antara motivasi belajar dengan kemandirian belajar mahasiswa calon guru sekolah dasar. Sampel yang dijadikan responden pada penelitian ini sebanyak 52 mahasiswa PGSD Universitas Mataram. Instrumen pengumpulan data menggunakan angket motivasi dan angket kemandirian belajar yang terdiri dari 30 item pernyataan. Bentuk angket yang digunakan dalam penelitian ini adalah angket skala likert dengan 4 pilihan alternatif jawaban. Teknik analisis data yang digunakan adalah uji korelasi Pearson Product Moment. Sebelum dilakukan uji korelasi maka terlebih dahulu memenuhi syarat uji asumsi klasik yaitu uji normalitas dan uji linearitas. Hasil uji normalitas didapatkan sig. $(0,927)$ lebih dari 0,05 maka data berdistribusi normal, kemudian hasil uji linearitas didapatkan sig. $(0,603)$ lebih dari 0,05 maka ada hubungan yang linear antara kedua variabel. Hasil analisis uji korelasi Pearson Product Moment menunjukkan nilai sig.(2 tailed) 0,000 kurang dari 0,05 dan $R_{\text {hitung }}(0,849)$ lebih dari $R_{\text {tabel }}(0,279)$ yang artinya ada hubungan yang signifikan antara motivasi dengan kemandirian belajar mahasiswa, dan derajat hubungan yang dihasilkan yaitu hubungan motivasi dengan kemandirian belajar mahasiswa berkorelasi sempurna.
\end{abstract}

Kata kunci: motivasi belajar, kemandirian belajar, mahasiswa

Belajar adalah kegiatan pokok dalam proses pendidikan. Dalam proses belajar, motivasi sangat diperlukan sebab tanpa motivasi seseorang tidak mungkin melakukan aktivitas belajar. Mahasiswa akan memiliki motivasi belajar yang tinggi jika mengetahui tujuan yang ingin 
dicapainya. Motivasi menjadi salah satu faktor pendorong kemandirian belajar yang merupakan perpaduan antara ketrampilan dan kemauan yang diperlukan untuk berkembangnya pemikiran seorang pelajar. Nefi et al., (2015) mengungkapkan bahwa semakin besar motivasinya maka semakin besar kemandirian belajar yang ditimbulkan. Mahasiswa yang motivasinya tinggi, akan tampak gigih, aktif dalam proses pembelajaran dan meningkatkan prestasi. Kemandirian belajar lainnya dapat terlihat dari pandai mengatur waktu belajar, tempat belajar, memilih strategi, dan bertanggungjawab dalam memanfaatkan sumber belajar secara mandiri (Tutpai \& Suharto, 2017). Motivasi merupakan bagian kompleks yang mempengaruhi seseorang untuk memilih ingin menghabiskan waktunya untuk apa, berapa banyak energi untuk menyelesaikan suatu masalah, dan bagaimana kegigihan orang tersebut mengatasi kesulitan dalam proses pembelajaran (Bakar, 2014).

Menurut Gusniwilda et al., (2014) Sikap belajar mahasiswa pada aspek kognitif berada pada kategori cukup, kurangnya kesadaran memahami materi sebelum perkuliahan dimulai, kurangnya pemahaman tentang pentingnya mengulang kembali materi yang telah disampaikan. Kebiasaan menunda menyelesaikan tugas-tugas juga masih tinggi. Sikap semacam ini menunjukkan rendahnya kemandirian belajar mahasiswa sehingga perlu adanya peningkatan motivasi. Untuk meningkatkan motivasi, ada beberapa hal yang bisa dilakukan, diantaranya membuat suasana baru dalam belajar, menuangkan keseriusan pada materi ajar, menyediakan kesempatan belajar yang menarik dan membiarkan seorang siswa untuk mengidentifikasi pengalaman belajarnya sendiri, atau dapat disebut kemandirian belajar.

Kemandirian belajar menurut Nurfadilah \& Hakim (2019) adalah sistem pembelajaran yang didasarkan pada kedisiplinan diri menggunakan metode belajar yang sesuai dengan dirinya, bersikap mandiri dalam menyelesaikan berbagai situasi disekitarnya sehingga seseorang dapat berpikir dan bertindak sendiri dalam proses belajarnya. Kemandirian belajar penting untuk siswa sekolah dasar hingga setingkat mahasiswa. Kemandirian belajar berkaitan dengan kekampuan seseorang bertanggung jawab pada dirinya. Oleh karena itu kemandirian belajar merupakan ciri kedewasaan orang terpelajar dan mampu mengatur dan mendisiplinkan diri dengan penuh keyakinan dan tanggung jawab atas tindakannya.

Kemandirian belajar dan motivasi belajar saling mempengaruhi untuk prestasi belajar seseorang. Motivasi dibutuhkan untuk awal proses, sehingga seseorang dapat mengatur waktunya dan belajar lebih efektif. Sedangkan kemandirian membuat semakin mahir mengatur proses belajarnya sendiri. Sehingga keduanya membuat belajar menjadi lebih mudah, dan hasil belajar maksimal (Fauzi \& Widjajanti, 2018).

Hasil survey di lapangan, kemandirian belajar mahasiswa calon guru sekolah dasar masih rendah. Hal ini dapat dilihat dari, kesiapan mereka sebelum perkuliahan, saat belajar di dalam kelas, setelah kelas selesai dan evaluasi maupun pengumpulan tugas. Penelitian (Hendrayana, 2014) juga membuktikan bahwa kemandirian belajar mahasiswa belum memenuhi harapan, seperti dapat dilihat dari membuat jadwal belajar dan memanfaatkan waktu luang untuk membaca materi perkuliahan.

Sebagai calon guru, mahasiswa diharapkan memiliki kemampuan untuk berinovasi dalam meningkatkan kualitas pendidikan. Oleh karenanya, membangun motivasi dan kemandirian belajar merupakan langkah awal untuk memulainya dari diri sendiri. Beberapa indikator yang harus dimiliki mahasiswa untu membangun hal tersebut adalah percaya diri, tanggungjawab, inisiatif dan disiplin. Berdasarkan latar belakang diatas, dalam penelitian ini akan melihat hubungan antara Motivasi Belajar dan Kemandirian Belajar Mahasiswa Calon Guru Sekolah Dasar. Sehingga secara strategis dari hasil penelitian nantinya dapat menjadi pertimbangan bagi pendidik untuk 
mengembangkan metode-metode untuk meningkatkan kemandirian belajar maupun motivasi belajar untuk mahasiswa pada khususnya.

\section{METODE}

Jenis penelitian ini adalah penelitian kuantitatif korelasi. Pada penelitian ini dilakukan untuk mengetahui bagaimana hubungan motivasi belajar dengan kemandirian belajar mahasiswa calon guru sekolah dasar. Penelitian ini dilaksanakan di Universitas Mataram pada program studi Pendidikan Guru Sekolah Dasar (PGSD). Populasi dalam penelitian ini adalah seluruh mahasiswa PGSD Universitas Mataram semester 2 dan semester 4. Pengambilan sampel menggunakan teknik simple random sampling dengan memilih satu kelas pada semester 2 dan satu kelas pada semester 4 yang dipilih secara acak. Dari pemilihan sampel secara acak, didapatkan sampel dari mahasiswa kelas $2 \mathrm{~F}$ dan kelas 4D yang berjumlah 52 mahasiswa.

Instrumen pengumpulan data yang digunakan pada penelitian ini adalah instrumen motivasi belajar dan kemandirian belajar yang berupa angket. Angket (kuesioner) merupakan teknik pengumpulan data yang efisien untuk dilakukan dengan cara memberikan beberapa pertanyaan atau pernyataan tertulis kepada responden (Fatihah, 2016). Angket yang digunakan adalah angket skala likert yang terdiri dari atas pilihan skala yaitu Selalu (SL), Sering (SR), Jarang (JR), dan Tidak Pernah (TP). Data yang diperoleh dari hasil angket kemudian dianalisis untuk mengetahui klasifikasi tingkat motivasi dan kemandirian belajar mahasiswa. Tabel 1 dibawah ini menyajikan pedoman klasifikasi yang digunakan adalah skala lima untuk mendeskripsikan hasil data kuantitatif angket (Widoyoko, 2017).

Tabel 1. Pedoman Konversi Data Kuantitatif ke Kualitatif

\begin{tabular}{ccc}
\hline Rumus & Rerata Skor & Klasifikasi \\
\hline$X>\bar{X}_{1}+1,8 \times s b_{i}$ & $X>102$ & Sangat Tinggi \\
\hline$\overline{X_{1}}+0,6 \times s b_{i}<X \leq \bar{X}_{1}+1,8 \times s b_{i}$ & $84<X \leq 102$ & Tinggi \\
\hline $\bar{X}_{4}-0,6 \times s b_{i}<X \leq \bar{X}_{1}+0,6 \times s b_{i}$ & $66<X \leq 84$ & Sedang \\
\hline $\bar{X}_{1}-1,8 \times s b_{i}<X \leq \bar{X}_{1}-0,6 \times s b_{i}$ & $48<X \leq 66$ & Rendah \\
\hline$X \leq \bar{X}_{1}-1,8 \times s b_{i}$ & $X \leq 48$ & Sangat Rendah \\
\hline
\end{tabular}

Untuk mendapatkan rerata skor diatas, terlebih dahulu dihitung rerata skor ideal $\left(\bar{X}_{i}\right)$ dan simpangan baku ideal $\left(S b_{i}\right)$. Rerata skor ideal $\left(\bar{X}_{i}\right)=1 / 2$ (skor maksimum ideal + skor minimum ideal), simpangan baku ideal $\left(s b_{i}\right)=1 / 6$ (skor maksimum ideal - skor minimum ideal), dan $X$ adalah skor empiris, dimana skor maksimum adalah 120 dan skor minimum adalah 30. Setelah dihitung skor empiris yang didapatkan dari hasil angket maka dihitung frekuensi dan persentase dari klasifikasi berdasarkan Tabel 1 di atas.

Selanjutnya, dalam penelitian ini dilakukan teknik analisis data yang digunakan untuk mengetahui tingkat hubungan antara motivasi dan kemandirian belajar dengan menggunakan analisis korelasi pearson product moment dengan bantuan program SPSS. Uji korelasi bertujuan untuk mengetahui tingkat keeratan hubungan antara motivasi dengan kemandirian belajar. Dasar pengambilan keputusan yaitu jika nilai signifikansi $<0,05$ maka berkorelasi, dan jika signifikansi $>0,05$ maka tidak berkorelasi atau $R_{\text {hitung }}>R_{\text {tabel }}$ maka berkolerasi dan $\mathrm{R}_{\text {hitung }}<\mathrm{R}_{\text {tabel }}$ maka tidak berkolerasi. Rumusan hipotesis yang digunakan dalam penelitian ini terdiri dari $H_{0}$ yaitu tidak ada hubungan yang signifikan antara motivasi dan kemandirian belajar mahasiswa calon guru sekolah dasar, dan hipotesi alternatif $\left(H_{a}\right)$ yaitu ada hubungan yang signifikan antara motivasi dan kemandirian belajar mahasiswa calon guru sekolah dasar. 
Kemudian, hasil analisis korelasi tersebut dilihat derajat hubungan kedua variable. Pedoman derajat hubungan kedua variabel dapat dilihat pada tabel 2 berikut.

\section{Tabel 2. Pedoman Derajat Hubungan}

\begin{tabular}{cl}
\hline Nilai Pearson Correlation & \multicolumn{1}{c}{ Kriteria Korelasi } \\
\hline $0,00-0,20$ & Tidak ada korelasi \\
\hline $0,21-0,40$ & Korelasi lemah \\
\hline $0,41-0,60$ & Korelasi sedang \\
\hline $0,61-0,80$ & Korelasi kuat \\
\hline $0,81-1,00$ & Korelasi sempurna \\
\hline
\end{tabular}

Sebelum dilakukan uji korelasi, terlebih dahulu dilakukan uji asumsi yaitu uji normalitas dan uji linearitas. Uji normalitas menggunakan Uji Kolmogorov Smirnov bertujuan untuk apakah nilai residual berdistribusi normal atau tidak. Dasar pengambilan keputusan uji normalitas yaitu jika nilai signifikansi > 0,05 maka nilai residual berdistribusi normal, dan jika nilai signifikansi < 0,05 maka nilai residual tidak berdistribusi normal. Selanjutnya dilakukan uji linearitas untuk mengetahui bentuk hubungan antaran variabel motivasi belajar dengan kemandirian belajar mahasiswa. Dasar pengambilan keputusan uji linearitas yaitu jika nilai signifikansi deviation from linearity > 0,05 maka terdapat hubungan yang linear antara motivasi belajar dengan kemandirian belajar, dan jika nilai signifikansi deviation from linearity $<0,05$ maka tidak terdapat hubungan yang linear antara motivasi belajar dengan kemandirian belajar mahasiswa.

\section{HASIL}

Angket motivasi belajar dan kemandirian belajar dibagikan kepada mahasiswa calon guru sekolah dasar sebanyak 52 mahasiswa yang terdiri dari mahasiswa semester 2 dan semester 4 . Pernyataan pada angket motivasi dan kemandirian belajar masing-masing terdiri dari 30 pernyataan dengan alternatif jawaban skala 1 sampai 4 . Hasil kedua angket kemudian dianalisis untuk mengetahui tingkat klasifikasi motivasi dan kemandirian belajar mahasiswa. Hasil data distribusi motivasi dan kemandirian belajar disajikan pada tabel berikut.

Tabel 3. Klasifikasi Motivasi dan Kemandirian Belajar Mahasiswa

\begin{tabular}{ccccc}
\hline \multirow{2}{*}{ Klasifikasi } & \multicolumn{2}{c}{ Motivasi Belajar } & \multicolumn{2}{c}{ Kemandirian Belajar } \\
\cline { 2 - 5 } & Frekuensi & Persentase & Frekuensi & Persentase \\
\hline Sangat Tinggi & 13 & $25 \%$ & 9 & $17 \%$ \\
\hline Tinggi & 29 & $56 \%$ & 34 & $65 \%$ \\
\hline Sedang & 9 & $17 \%$ & 8 & $15 \%$ \\
\hline Rendah & 1 & $2 \%$ & 1 & $2 \%$ \\
\hline Sangat Rendah & 0 & $0 \%$ & 0 & $0 \%$ \\
\hline
\end{tabular}

Perbandingan frekuensi motivasi belajar dan kemandirian belajar mahasiswa calon guru sekolah dasar berdasarkan klasifikasi disajikan pada gambar berikut. 


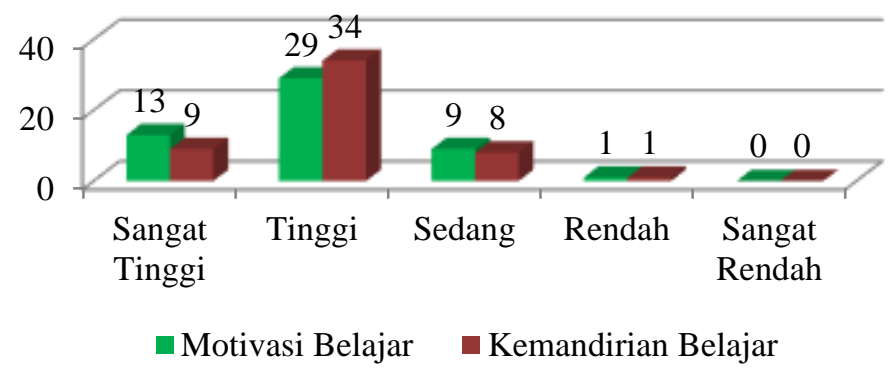

\section{Gambar 1. Perbandingan Motivasi dan Kemandirian Belajar Mahasiswa}

Berdasarkan Tabel 3 dan Gambar 1 di atas dapat diketahui hasil angket motivasi belajar mahasiswa yang berada pada klasifikasi sangat tinggi sebesar 25\% atau 13 dari 52 mahasiswa, motivasi tinggi sebesar 56\% atau 29 mahasiswa, motivasi sedang sebesar 17\% atau 9 mahasiswa, motivasi rendah sebesar $2 \%$ atau hanya 1 mahasiswa, dan tidak ada mahasiswa yang memiliki motivasi sangat rendah. Secara umum, rata-rata tingkat motivasi mahasiswa berada pada klasifikasi tinggi. Kemudian dilihat dari hasil angket kemandirian belajar diketahui bahwa mahasiswa yang memiliki kemandirian belajar sangat tinggi sebesar $17 \%$ atau 9 mahasiswa, kemandirian belajar tinggi sebesar $65 \%$ atau 34 mahasiswa, kemandirian belajar sedang $15 \%$ atau 8 mahasiswa, kemandirian belajar rendah sebesar 2\% atau 1 mahasiswa dan tidak ada mahasiswa yang memiliki kemandirian belajar sangat rendah. Kemudian secara umum, rata-rata tingkat kemandirian belajar mahasiswa berada pada klasifikasi tinggi. Artinya bahwa tingkat motivasi dan kemandirian belajar mahasiswa calon guru sekolah dasar tergolong tinggi.

Selanjutnya untuk mengetahui hubungan antara variabel motivasi belajar dan kemandirian belajar dilakukan uji statistic yaitu dengan uji korelasi pearson product moment dengan berbantuan program SPSS. Namun sebelum dilakukan uji korelasi, terlebih dahulu dilakukan uji asumsi klasik sebagai syarat untuk uji korelasi. Uji asumsi klasik yang digunakan adalah uji statistik normalitas dan uji statistik linearitas. Pada uji normalitas dapat dirumuskan hipotesisnya yaitu $\mathrm{H}_{0}$ : data yang diperoleh tidak berdistribusi normal, dan $\mathrm{H}_{\mathrm{a}}$ : data yang diperoleh berdistribusi normal. Hasil analisis uji normalitas Kolomogrov Smirnov dengan berbantuan program SPSS dapat dilihat pada tabel berikut.

Tabel 4. Output Hasil Uji Normalitas Kolmogorov Smirnov

\begin{tabular}{llr}
\hline & & Unstandardized Residual \\
\hline $\mathrm{N}$ & & 52 \\
\hline Normal Parameters $^{\mathrm{a}}$ & Mean & .0000000 \\
\cline { 2 - 3 } & Std. Deviation & 5.80642137 \\
\hline \multirow{2}{*}{ Most Extreme Differences } & Absolute & .076 \\
\cline { 2 - 3 } & Positive & .076 \\
\cline { 2 - 3 } & Negative & -.074 \\
\hline Kolmogorov-Smirnov Z & & .546 \\
\hline Asymp. Sig. (2-tailed) & & .927 \\
\hline
\end{tabular}


Berdasarkan hasil uji normalitas pada tabel 4 di atas didapatkan signifikansi sebesar $0,927>0,05$. Sesuai dengan dasar pengambilan keputusan uji normalitas jika sig. $(0,927)>\alpha(0,05)$ maka nilai residual dari data kedua variabel berdistribusi normal. Oleh karena itu rumusan hipotesis $\mathrm{H}_{0}$ ditolak dan $\mathrm{H}_{\mathrm{a}}$ diterima artinya bahwa data yang diperoleh berdistribusi normal. Selanjutnya uji asumsi kedua yaitu uji linearitas untuk mengetahui bentuk hubungan antara kedua variabel. Rumusan hipotesis pada uji linearitas pada penelitian ini yaitu $\mathrm{H}_{0}$ : tidak ada hubungan yang linear antara motivasi belajar dengan kemandirian belajar mahasiswa, $\mathrm{H}_{\mathrm{a}}$ : ada hubungan yang linear antara motivasi belajar dengan kemandirian belajar mahasiswa. Berdasarkan hasil output uji linearitas dengan bantuan SPSS didapatkan nilai signifikansi deviation from linearity sebesar 0,603 . Sesuai dengan dasar pengambilan keputusan dimana sig. $(0,603)>\alpha(0,05)$, maka $\mathrm{H}_{0}$ ditolak dan $\mathrm{H}_{\mathrm{a}}$ diterima. Artinya bahwa ada hubungan yang linear antara motivasi dengan kemandirian belajar mahasiswa. Karena kedua asumsi kelasik terpenuhi maka dilanjutkan dengan uji korelasi.

Uji korelasi person product moment digunakan untuk mengetahui tingkat keeratan hubungan kedua variabel. Rumusan hipotesis dalam penelitian ini yaitu $\mathrm{H}_{0}$ : tidak ada hubungan yang signifikan antara motivasi dengan kemandirian belajar mahasiswa, dan $\mathrm{H}_{\mathrm{a}}$ : ada hubungan yang signifikan antara motivasi dengan kemandirian belajar mahasiswa. Output hasil analisis uji korelasi ditunjukkan pada tabel berikut.

Tabel 5. Output Hasil Analisis Korelasi

\begin{tabular}{llrr}
\hline & & Motivasi & \multicolumn{2}{c}{$\begin{array}{c}\text { Kemandirian } \\
\text { Belajar }\end{array}$} \\
\hline \multirow{2}{*}{ Motivasi } & Pearson Correlation & 1 & $.849^{* * *}$ \\
\cline { 2 - 4 } & Sig. (2-tailed) & 52 & .000 \\
\cline { 2 - 4 } & $\mathrm{N}$ & $.849^{* *}$ & 52 \\
\hline Kemandirian Belajar & Pearson Correlation & .000 & 1 \\
\cline { 2 - 4 } & Sig. (2-tailed) & 52 & 52 \\
\cline { 2 - 4 } & $\mathrm{N}$ & & \\
\end{tabular}

Berdasarkan tabel 5 di atas dapat diketahui nilai Sig. (2-tailed) antara motivasi dan kemandirian belajar sebesar 0.000 kurang dari 0,05. Kemudian nilai R hitung (Pearson Correlation) sebesar 0,849 dan nila $\mathrm{R}$ tabel pada taraf signifikansi 5\% sebesar 0,279 yang artinya $\mathrm{R}_{\text {hitung }}(0,849)>\mathrm{R}_{\text {tabel }}(0,279)$. Dasar pengambilan keputusan hipotesis dapat dilihar dari hasil analisis dimana Sig. $<0,05$ atau $\mathrm{R}_{\text {hitung }}>\mathrm{R}_{\text {tabel }}$ maka $\mathrm{H}_{0}$ ditolak dan $\mathrm{H}_{\mathrm{a}}$ diterima. Artinya bahwa ada hubungan yang signifikan antara motivasi dan kemandirian belajar mahasiswa calon guru sekolah dasar. Kemudian untuk menentukan derajat hubungan diantara kedua variabel dapat dilihat dari nilai pearson correlation yaitu sebesar 0,849 yang artinya motivasi dan kemandirian belajar mahasiswa berkolerasi sempurna. Sedangkan nilai positif pada pearson correlation menunjukkan bahwa semakin tinggi motivasi belajar maka semakin tinggi kemandirian belajar mahasiswa, begitu sebaliknya semakin rendah motivasi belajar maka semakin rendah pula kemandirian belajar mahasiswa calon guru sekolah dasar.

\section{PEMBAHASAN}

Berdasarkan hasil uji normalitas didapatkan signifikansi sebesar 0,927 >0,05 maka nilai residual dari data kedua variabel berdistribusi normal. Berdasarkan hasil output uji linearitas dengan bantuan SPSS didapatkan nilai signifikansi deviation from linearity sebesar 0,603, Artinya 
bahwa ada hubungan yang linear antara motivasi dengan kemandirian belajar mahasiswa. Berdasarkan hasil Uji korelasi person product moment dapat diketahui nilai Sig. (2-tailed) antara motivasi dan kemandirian belajar sebesar 0.000 kurang dari 0,05, Artinya bahwa ada hubungan yang signifikan antara motivasi dan kemandirian belajar mahasiswa calon guru sekolah dasar. Dapat dikatakan bahwa semakin tinggi motivasi belajar maka semakin tinggi kemandirian belajar mahasiswa, begitu sebaliknya semakin rendah motivasi belajar maka semakin rendah pula kemandirian belajar mahasiswa calon guru sekolah dasar.

Hasil penelitian ini sejalan dengan pernyataan Astuti (2019) dalam penelitiannya bahwa mahasiswa yang memiliki tingkat motivasi yang tinggi maka kemandirian belajar akan semakin tinggi. Motivasi belajar dapat mempengaruhi kemandirian belajar sebab adanya keuletan dan ketekunan, keinginan menyelesaikan tugas tepat waktu, keinginan bertanya jika ada hal yang tidak dimengerti sehingga kemandirian untuk belajar dapat dilaksanakan sesuai keinginan diri sendiri (Damayanti et al., 2015). Selain terdapatnya hubungan yang signifikan antara motivasi dan kemandirian belajar, kedua variabel tersebut dapat meningkatkan prestasi belajar kognitif (Rijal \& Bachtiar, 2015; Fatihah, 2016; Saeid \& Eslaminejad, 2017). Mahasiswa yang memiliki motivasi belajar yang tinggi akan memiliki minat dan perhatian terhadap pelajaran, semangat dalam melaksanakan tugas baik tugas mandiri maupun kelompok, sehingga motivasi belajar memiliki hubungan yang positif dengan kemandirian belajar.

\section{SIMPULAN}

Dari hasil penelitian dapat diketahui bahwa rata-rata motivasi dan kemandirian belajar mahasiswa calon guru sekolah dasar berada pada klasifikasi tinggi. Berdasarkan hasil analisis korelasi pearson product moment didapatkan nilai sig.(2 tailed) sebesar 0,000 $<0,05$ dan $R_{\text {hitung }}(0,849)>R_{\text {tabel }}(0,279)$. Hal tersebut menunjukkan bahwa ada hubungan yang signifikan antara motivasi belajar dengan kemandirian belajar mahasiswa. Derajat hubungan kedua variabel dilihat berdasarkan nilai pearson correlation dimana nilai pearson correlation tersebut sebesar 0,849 yang berada pada kategori derajat korelasi yang sempurna. Artinya bahwa hubungan kedua variabel antara motivasi dan kemandirian belajar berkorelasi sempurna. Kemudian dilihat dari hasil nilai pearson correlation yang positif, artinya semakin tinggi motivasi maka semakin tinggi kemandirian belajar mahasiswa, atau sebaliknya semakin rendah motivasi maka semakin rendah kemandirian belajar mahasiswa calon guru sekolah dasar.

Berdasarkan hasil penelitian ini disarankan untuk dapat terus meningkatkan motivasi sehingga kemandirian belajar mahasiswa juga meningkat. Dengan meningkatnya motivasi dan kemandirian belajar diharapkan juga dapat meningkatkan prestasi belajar mahasiswa. Selanjutnya kepada peneliti lainnya yang ingin membuat penelitian sejenis untuk menggunakan sampel penelitian yang lebih luas guna mendapatkan hasil yang lebih akurat. Kemudian, selain kedua variabel yang digunakan dalam penelitian ini, dapat juga menggunakan variabel lain untuk dianalisis korelasinya sehingga dapat diketahui apa saja faktor-faktor yang dapat mempengaruhi hasil belajar.

\section{DAFTAR RUJUKAN}

Astuti, B. (2019). Profil Kemandirian Belajar Mahasiswa Bimbingan dan Konseling. Jurnal Penelitian Ilmu Pendidikan, 12(1), 63-74. https://doi.org/10.1017/CBO9781107415324.004

Bakar, R. (2014). The Effect of Learning Motivation on Students Productive Competencies in Vocational High School, West Sumatra. International Journal of Asian Social Science, 4(6), 722-732. 
Damayanti, N., Siregar, M., \& Harahap, P. E. (2015). The Relationship Between Learning Motivation And Self-Directed Learning On Students Of Medan Area University. Jurnal Pemikiran \& Penelitian Psikologi, 10(2), 18-24.

Fatihah, M. Al. (2016). Hubungan Antara Kemandirian Belajar dengan Prestasi Belajar PAI Siswa Kelas III SDN Panularan Surakarta. At-Tarbawi: Jurnal Kajian Kependidikan Islam, 1(2), 197-208. https://doi.org/10.22515/attarbawi.v1i2.200

Fauzi, A., \& Widjajanti, D. B. (2018). Self-regulated learning: The effect on student's mathematics achievement. Journal of Physics: Conference Series, 1-8. https://doi.org/10.1088/1742-6596/1097/1/012139

Gusniwilda, A., Syukur, Y., \& Nurfahanah, N. (2016). Sikap dan Kebiasaan Belajar Mahasiswa. Konselor, 3(2), 42. https://doi.org/10.24036/02014321871-0-00

Hendrayana, A. S. (2014). Motivasi Belajar, Kemandirian Belajar dan Prestasi Belajar Mahasiswa Beasiswa BIDIKMISI DI UPBJJ UT Bandung. Jurnal Pendidikan Terbuka Dan Jarak Jauh, 15(2), 81-87.

Nefi, D., Siregar, M., \& Harahap, P. E. (2015). Hubungan Antara Motivasi Belajar dan Kemandirian Belajar pada Mahasiswa Universitas Sumatera Utara. Jurnal Psikologia, 10(1), $18-24$.

Nurfadilah, S., \& Hakim, D. L. (2019). Kemandirian Belajar Siswa dalam Pembelajaran Matematika. Prosiding Seminar Nasional Matematika Dan Pendidikan Matematika Sesiomadika 2019, 1214-1223.

Rijal, S., \& Bachtiar, S. (2015). Hubungan antara Sikap, Kemandirian Belajar, dan Gaya Belajar dengan Hasil Belajar Kognitif Siswa. Jurnal Bioedukatika, 3(2), 15-20. https://doi.org/10.26555/bioedukatika.v3i2.4149

Saeid, N., \& Eslaminejad, T. (2017). Relationship between Student's Self-Directed-Learning Readiness and Academic Self-Efficacy and Achievement Motivation in Students. International Education Studies, 10(1), 225-232. https://doi.org/10.5539/ies.v10n1p225

Tutpai, G., \& Suharto, T. N. E. D. (2017). Hubungan Antara Motivasi Belajar dan Dukungan Sosial Orangtua dengan Kemandirian Belajar pada Mahasiswa. Jurnal Keperawatan STIKES Suaka Insan, 2(2), 1-11.

Widoyoko, E. P. (2017). Evaluasi Program Pembelajaran Panduan Praktis Bagi Pendidik Dan Calon Pendidik. Jakarta: Pustaka Pelajar. 